\title{
Three Newly Recorded Species of the Genera Acaphylla Keifer and Calacarus Keifer (Prostigmata: Eriophyidae) from Camellia spp. (Theaceae) in Korea
}

\author{
Jong-Ho Lee, Sunghoon Jung ${ }^{1}$ and Seunghwan Lee*
}

\section{동백나무류에서 발생하는 국내 미기록 혹응애류 3종에 대한 보고}

\author{
이종호 · 정성훈 ${ }^{1} \cdot$ 이승환* \\ 서울대학교 농업생명과학연구원, ${ }^{1}$ 충남대학교 농업생명과학대학 응용생물학과
}

\begin{abstract}
Three species belonging to genera Acaphylla Keifer and Calacarus Keifer (Prostigmata: Eriophyidae) that cause damage to Camellia (Theaceae) plants, have been newly recorded in Korea. The three species, Acaphylla theae (Watt), Acaphylla theavagrans Kadono, and Calacarus carinatus (Green), have been redescribed and illustrated. Keys to Korean species of the genus Acaphylla; their distribution; and biological information, such as host plants and damage symptoms, are also presented.
\end{abstract}

Key words: Acaphylla, Calacarus, Camellia spp., newly recorded species, key, Eriophyidae, Korea

초 록: 한국산 동백나무류에서 서식하는 3종의 국내 미기록 혹응애(전기문목: 혹응애과), Acaphylla theae (Watt), A. theavagrans Kadono 및 Calacarus carinatus (Green)에 대한 분류학적 설명과 주요형질의 삽화를 제공하고, 기주식물과 피해양상 등의 생물학적 정보 또한 제공한다.

검색어: 쐐기혹응애속, 민등혹응애속, 동백나무류, 미기록 종, 검색표, 혹응애과, 한국

Eriophyid mites are highly specific parasites of plants, potentially attacking all plant parts other than the roots (Westphal and Manson, 1996). Although they are obligatory plant-feeding mites, they are poorly understood and often overlooked because of their extremely small size (average body length, 200 $\mu \mathrm{m})$ and cryptic habits (Manson, 1984).

A total of 18 species in 8 genera of Eriophyidae have been reported in Korea (Anonymous, 1928; Kim, 1965; Huang, 1972; Anonymous, 1973; Anonymous, 1986; Baker et al., 1986; Kim, 1990; Choi et al., 1992; Park et al., 1996; Na et al., 1998;

*Comesponding author: seung@snu.ac.kr

Received September 26 2013; Revised November 12013 Accepted November 272013
Lee et al., 1999). Although 5 eriophyid species have been obtained from Camellia spp. globally (Amrine and Stasny, 1994; Channabasavanna, 1996), there have been no records of them in Korea. After a long-term survey of eriophyid fauna in Korea, we, herein, report new occurrences of three species on Camellia spp. in Korea: Acaphylla theae (Watt), A. theavagrans Kadono, and Calacarus carinatus (Green).

Plant samples were collected and examined for the presence of mites by using a field microscope (Field Microscope Mini; Nikon, Japan) and a stereomicroscope (SteREO Discovery. V12; Carl Zeiss, Germany). They were mounted on slides, according to Keifer's methodology (Keifer, 1952; Kadono, 1995). The classification and terminology of Amrine et al. (2003), and Amrine and Manson (1996) were used. Measurements 
were undertaken according to Amrine and Manson (1996) and de Lillo et al. (2010), and given in micrometers.

\section{Systematic Accounts}

\section{Tribe Acaricalini Amrine and Stasny, 1994}

Acaricalini Amrine and Stasny, 1994, Catalog Eriophyoidea: 767.

Type Genus: Acaricalus Keifer, 1940b, ES X, BCDA 29(3): 214.

DIAGNOSIS. Scapular setae (sc) absent or present and their tubercles set well ahead or near rear margin of shield, orienting setae in variable directions. Opisthosomal annuli evenly down curved laterally or individually extended laterally into blunt lobes. Tarsal empodia of legs I and II with main shaft moderately to deeply divided.

\section{Genus Acaphylla Keifer, 1943}

"Swae-gi-hog-eung-ae-sok"

Acaphylla Keifer, 1943, ES XIII, BCDA 32: 214.

Type Species: Acaphylla steinwedeni Keifer, 1943, ES. XIII, BCDA 32: 215.

DIAGNOSIS. Body robust fusiform; opisthosoma strong differentiated into dorsal and ventral annuli, ventral annuli slightly more numerous; middorsal ridge present; Gnathosoma moderate length. Palp genual seta $d$ bifurcate. Scapular tubercles ahead of rear shield margin; $s c$ directed upwards, anteriorly, or medially. Legs with normal setation except leg II genual seta $\left(l^{\prime \prime}\right)$ lacking; tarsal empodia divided. Coxae I $1 b$ absent. Opisthosoma with all setae. Female genitalia with internal apodeme of normal length.

\section{Key to species of the genus Acaphylla in Korea}

1. Prodorsal shield without transverse lines at the center of admedian lines; scapulartubercles present, but tiny, sc small, directed medially

A. theae (Watt)

- Prodorsal shield with transverse lines at the center of admedian lines; scapular tubercles nearly vestigial, sc very small, directed medially

A. theavagrans Kadono

\section{Acaphylla theae (Watt, 1898) (Fig. 1 and 4)}

"Dong-baek-hog-eung-ae"

Phytoptus theae Watt, 1898, Office, Supt. Govt. Printing,
Calcutta, India 1898: 400-408 (TL: India; TH:.Camellia sinensis (L) Kuntze.).

Acaphylla steinwedeni Keifer. 1943, ES XIII, BCDA 32: 215 (synonymized by Das and Sengupta, 1958, J. Zool. Soc. India 10: 39-48).

Acaphylla theae: Keifer, 1954, ES XXII, BCDA 43: 126.

DIAGNOSIS. This species differs from others by the prodorsal shield with a slightly indented frontal lobe, frontal lobe in lateral view with a ventral knob, and the lack of transverse line at the center of admedian lines.

FEMALE. Body fusiform, blunt anteriorly, orange, 170-194 long, 70-75 wide. Gnathosoma 30 long, dorsal pedipalp genual setae 14-19 long, abruptly bent and bifurcate. Prodorsal shield 62-68 long, 75-78 wide; with centro-longitudinal ridge made by segmented median line and admedian lines; frontal lobe indented, projecting over gnathosoma; design of relatively few longitudinal and transverse lines and with lateral granules; scapular tubercles well ahead of rear margin; scapular setae $s c$
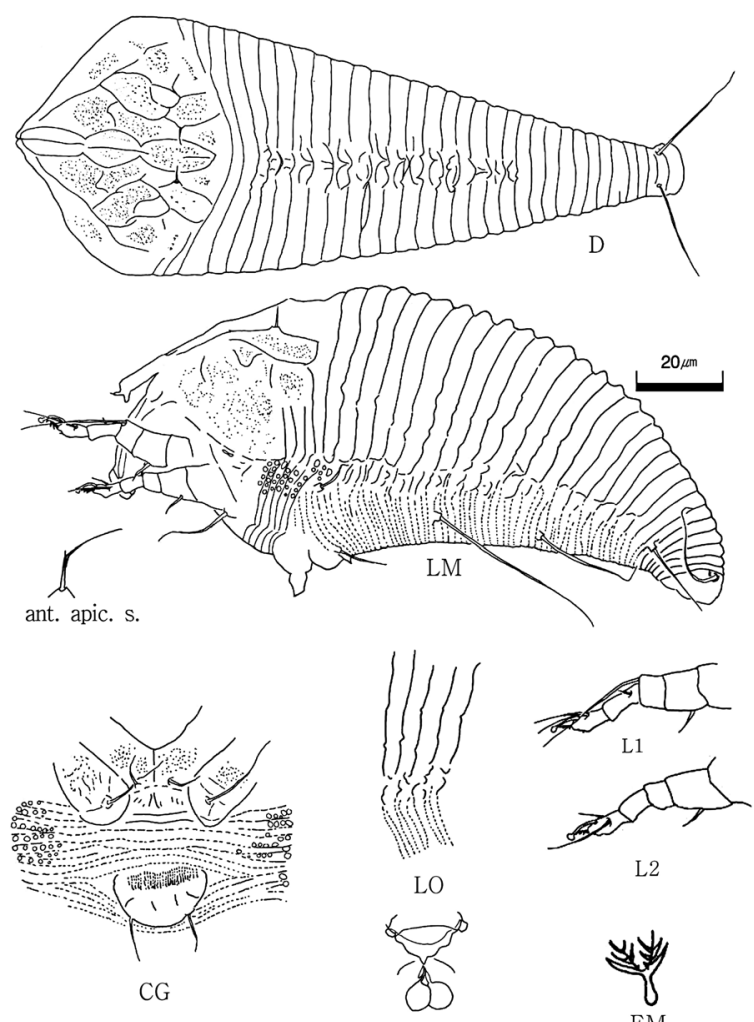

L2

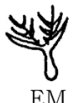

Fig. 1. Acaphylla theae (Watt). (CG: coxigenital region; D: dorsal view; EM: empodium; IG: female internal genitalia; LM: lateral view; LO: lateral opisthosoma, L1: leg I; L2: leg II; ant. apic. s: dorsal pedipalp genual setae $(d))$. 


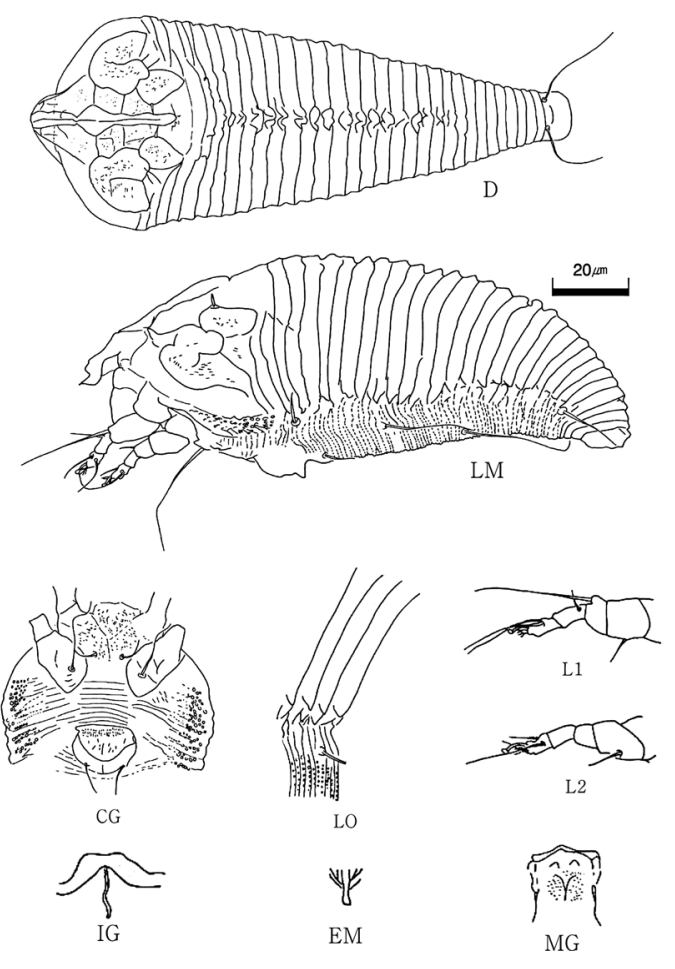

Fig. 2. Acaphylla theavagrans Kadono. (CG: coxigenital region; D: dorsal view; EM: empodium; IG: female internal genitalia; LM: lateral view; LO: lateral opisthosoma, L1: leg I; L2: leg II).
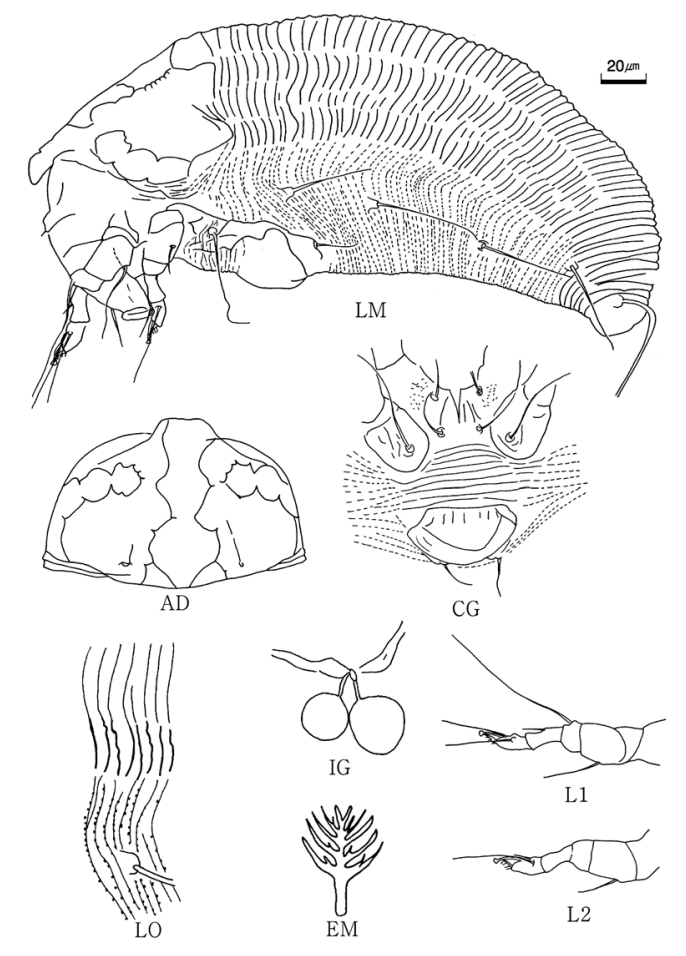

Fig. 3. Calacarus carinatus (Green). (AD: anteriodorsal view; CG: coxigenital region; EM: empodium; IG: female internal genitalia; LM: lateral view; LO: lateral opisthosoma, L1: leg I; L2: leg II).

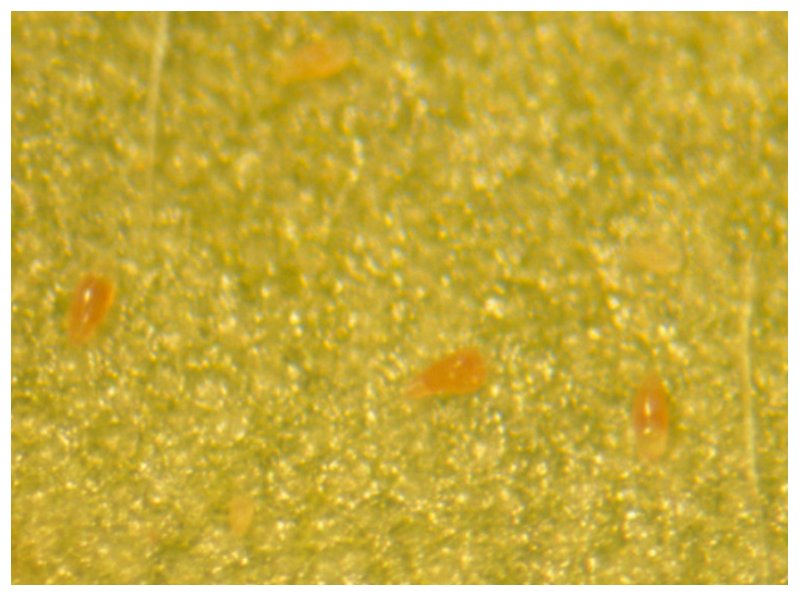

Fig. 4. Acaphylla theae (Watt); female and immature mites on lower leaf surface of Camellia japonica.

5 long, directed centrad and upward. Opisthosoma with middorsal ridge; dorsal annuli 29-30 without microtubercles; ventral annuli 68-70, microtubercles small, beadlike, touching rear annular margins. Setae $h 1$ absent; tubercles tiny, but vestigial. Coverflap with numerous broken longitudinal lines and granules basally and 4-5 irregular longitudinal lines apically; coxae III setae $3 a$ 10-12 long. Coxae I and II with granules; sternal line present; coxae I seta $1 b$ absent. Leg II antaxial genual seta $l$ " absent; empodia divided, 3-rayed; tarsal solenidia knobbed.

MALE. Present, smaller than female, about 150 long, 55 wide, with bilobed frontal lobe more apparent.

MATERIALS EXAMINED. 21 , $3 \sigma^{\top}$ (Coll.\#010422-2), Seonunsa Temple, Gochang, JeollaBuk-do, 22.iv.2001, Jong-Ho Lee, on Camellia japonica L.

HOST PLANTS. Camellia japonica L., C. sasanqua Thumb. (Theaceae)

DAMAGE SYMPTOM. Mites are vagrant on lower leaf surface and live under floral bud scales; sometimes causing leaf rust.

DISTRIBUTION. Korea (JeollaBuk-do); China, Japan, India, Malaysia, Taiwan; Italy, USA (Channabasavanna, 1996; Hong \& Zhang, 1996; Kadono, 1992; Keifer, 1943).

\section{Acaphylla theavagrans Kadono, 1992 (Fig. 2 and 5)}

"Cha-hog-eung-ae"

Acaphylla theavagrans Kadono, 1992, Acta Arachnol. 41(2): 


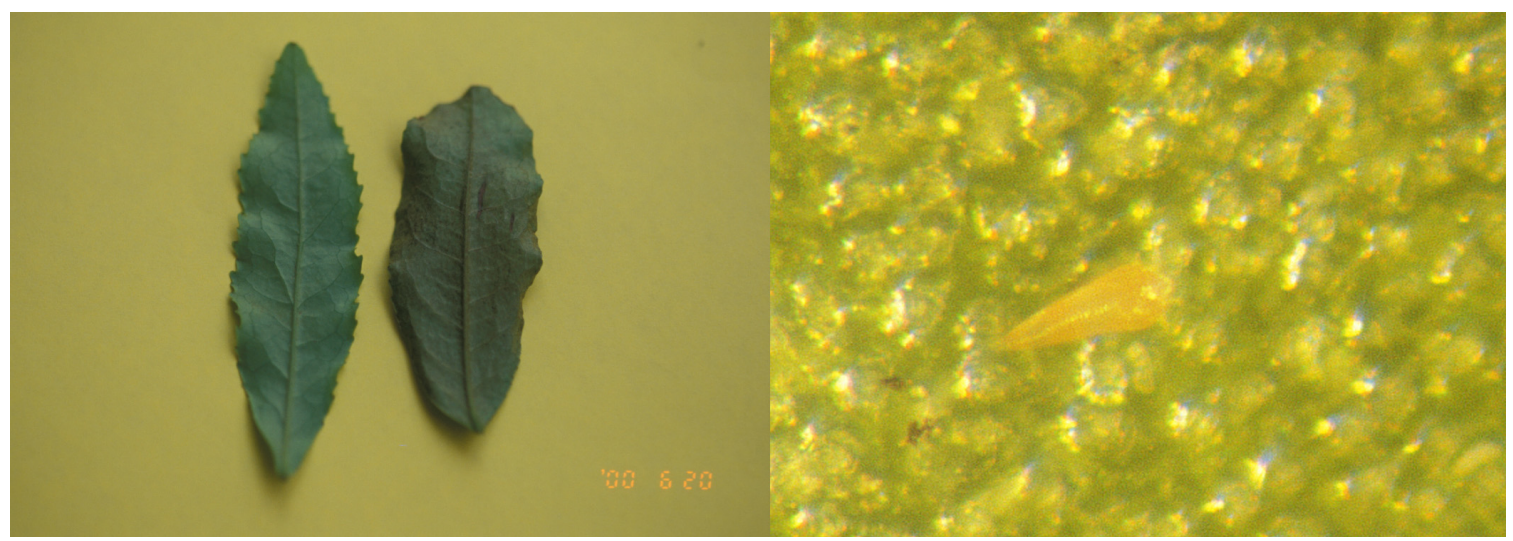

Fig. 5. Acaphylla theavagrans Kadono. Damage symptom (health leaf (left) and infested leaf (right)) and female mite on lower leaf surface of Camellia sinensis.

149 (TL: Hyogo Pref., Japan; TH: Camellia sinensis (L.) Kuntze).

DIAGNOSIS. This species differs from others by the prodorsal shield with indented frontal lobe and by transverse line at the center of admedian lines.

FEMALE. Body fusiform, blunt anteriorly, orange color, 180-210 long, 70-80 wide. Gnathosoma bent down, 30 long; dorsal palp genual setae 14-19 long, abruptly bent, bifurcate. Prodorsal shield subsemicircular, 60-64 long, 70-83 wide; frontal lobe slightly indented, shield design with longitudinal lines and granules; faint, segmented median line and complete admedian lines forming pen-point shaped central longitudinal figure; submedian and lateral lines forming network pattern with transverse lines, especially transverse line at the center of admedian line apparent; scapular tubercles well ahead of rear margin, but vestigial; scapular setae sc 4 long, directed centrad and upward. Opisthosoma with middorsal ridge; dorsal annuli 29-33 without microtubercles; ventral annuli 69-74; microtubercles small, beadlike, touching rear annular margins. Setae $h l$ absent, tubercles vestigial. Coverflap with numerous broken longitudinal lines and granules basally and 5-7 irregular longitudinal lines apically; coxae III setae $3 a$ 10-12 long. Coxae I with granules, coxae II smooth; sternal line present, faint. Empodia divided, 3-rayed; tarsal solenidia knobbed.

MALE. Present, smaller than female, about 160 long, 60 wide.

MATERIALS EXAMINED. 15 \% , $10^{\top}$ (Coll.\#000615-2), Ssanggye Temple, Hadong, GyeongsangNam-do , 15.vi.2000, Jong-Ho Lee, on Camellia sinensis (L.) Kuntze ; 6 우 (Coll. \#050609-1), Boseong, JeollaNam-do, 9.vi.2005, Jong-Ho Lee, on C. sinensis (L.) Kuntze ; 2 ㅇ (Coll. .\#090710-2), Seonheul,
Jocheon, Jeju, Jeju-do, 10.vii.2009, Jeong-Hup Song, on Camellia sinensis (L.) Kuntze.

HOST PLANT. Camellia sinensis (L.) (Theaceae).

DAMAGE SYMPTOM. Vagrant on lower leaf surface and causing leaf rust (Fig. 4).

DISTRIBUTION. Korea (GyeongsangNam-do, JeollaNam-do, Jeju-do); Japan, Taiwan (Channabasavanna, 1996; Kadono, 1992).

REMARKS. This species was first reported from Japan as a new species, because the transverse line at the center of admedian lines of prodorsal shield differs from the very similar species, A. theae (Watt) (Kadono, 1992). Additionally the scapular setal tubercles of $A$. theavagrans Kadono is vestigial, while those of $A$. theae (Watt) is tiny not vestigial.

\section{Tribe Calacarini Amrine and Stasny, 1994}

Calacarini Amrine and Stasny, 1994, Catalog Eriophyoidea: 768

Type Genus: Calacarus Keifer, 1940b, ES X, BCDA 29: 163

DIAGNOSIS. Scapular setae $(s c)$ vestigial or absent. Opisthosomal annuli evenly down curved laterally or individually extended laterally into blunt lobes. Tarsal empodium of legs I and II with main shaft entire.

\section{Genus Calacarus Keifer, 1940}

"Min-deung-hog- eung-ae-sok"

Calacarus Keifer, 1940b, ES X, BCDA 29: 163.

Type Species: Calacarus pulviferus Keifer, 1940b, ES X, 


\section{BCDA 29: 163-164.}

DIAGNOSIS. Body robust fusiform; opisthosoma strong differentiation into dorsoventrally, ventral annuli slightly more numerous; opisthosoma with at least a longitudinal ridge and two longitudinal subdorsal ridges present. Gnathosoma long, abruptly bent down. Prodorsal shield usually with tubercles, but setae minute or absent. Legs with normal setation except leg II antaxial genual setae ( $\left(l^{\prime \prime}\right)$ lacking; tarsal empodia simple. Coxae with normal setation. Opisthosoma with all setae. Female genitalia with internal apodeme of normal length.

\section{Calacarus carinatus (Green, 1890) (Fig. 3 and 6)}

\section{"Cha-geom-eun-hog-eung-ae"}

Typhlodromus carinatus Green, 1890, Insect Pests of the tea plant: 35 (TL: Colombo, Sri Lanka; TH: Camellia sinensis (L.) Kuntze).

Eriophyes carinatus: Nalepa, 1923, Marcellia 29(1-3): 25-66.

Calacarus carinatus: Keifer, 1955, Pan-Pacific Entomol. 31(3): 115.

Epitrimerus adornatus Keifer, 1940a, ES VIII, BCDA 29: 32.

DIAGNOSIS. This species differs from others by the purple body color, 5 longitudinal wax bearing ridges on opisthosoma, cellular pattern of prodorsal shield without scapular setae, and absence of the leg II genual setae $\left(l^{\prime \prime}\right)$.

FEMALE. Body robust fusiform, dull deep-purple, shield lines and dorsal ridges with white wax, 190-240 long, 79-93 wide. Gnathosoma 55 long, large and curved down. Prodorsal shield design forming a cellular pattern, 50-63 long, 71-85 wide; with round frontal lobe; scapular tubercles apparently present, scapular setae absent. Dorsal annuli 52-68; with five dorsal longitudinal ridges, smooth. Ventral annuli 69-79; microtubercles small, beadlike, on rear annular margins. Setae $h 1$ absent. Coverflap smooth with 11 short faint lines; coxae III setae $3 a$ 13-16 long. Coxae smooth, Empodia 5-rayed; tarsal solenidia strongly knobbed.

MALE. Not observed; male is known in Japan, which is smaller than female (Kadono, 1995).

MATERIALS EXAMINED. 8 \% (Coll.\#010512-1), Wonnam, Gangjin, JeollaNam-do, 12.v.2001, Jeong-Woo Seo, on Camellia sinensis (L.) Kuntze; 4 q (Coll.\#090515-2), Dongyoul, Whoecheon, Boseong, JeollaNam-do, 15.v.2009, Jong-Ho Lee, on Camellia sinensis (L.) Kuntze; 2 우 (Coll.\#090710-1),

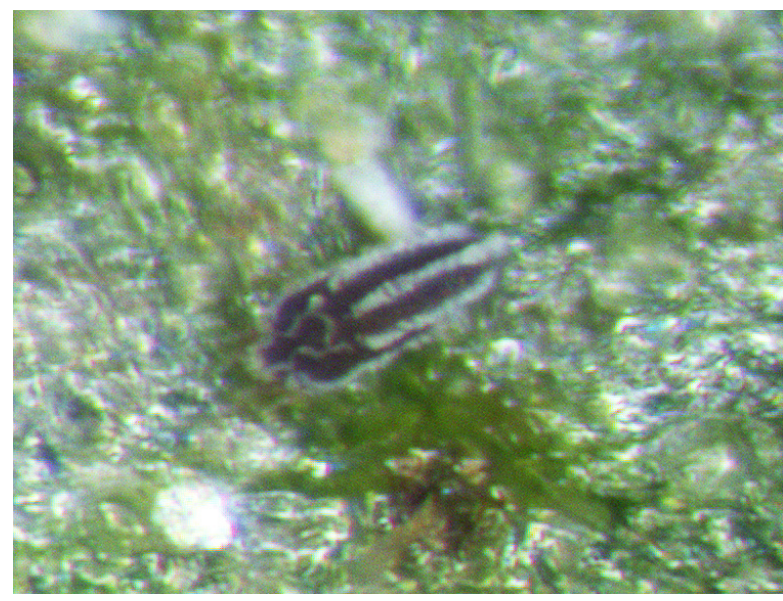

Fig. 6. Calacarus carinatus (Green). Female mites on lower leaf surface of Camellia sinensis.

Sanggui, Eweol, Jeju, Jeju-do, 10.vii.2009, Jeong-Hup Song, on Camellia sinensis (L.) Kuntze.

HOST PLANTS. Camellia sinensis (L.) (Theaceae), $C$. caudata (Wallich); C. japonica L.; C. kissi (Wallich); Capsicum annuum L.; Viburnum opulus L. (Caprifoliaceae).

DAMAGE SYMPTOM. Vagrant on lower leaf surface. It may cause bronzing and leaving white cast skin streaks on both leaf surfaces.

DISTRIBUTION. Korea (JeollaNam-do, Jeju-do); Cambodia, China, Japan, India, Indonesia, Laos, Malaysia, Sri Lanka, Taiwan, Vietnam; Italy, Portugal, Spain, USSR; USA; Australia, New Zealand (Channabasavanna, 1996; Hong \& Zhang, 1996; Manson, 1984)

\section{Literature Cited}

Amrine, J.W.J., Manson, D.C.M., 1996. Preparation, mounting and descriptive study of eriophyoid mites, in: Lindquist E.E., Sabelis M.W., Bruin J. (Eds), Eriophyoid mites - Their biology, natural enemies and control. Elsevier Science Publ., Amsterdam, pp. 383-396.

Amrine, J.W.J., Stasny, T.A., 1994. Catalog of the Eriophyoidea (Acarina: Prostigmata) of the world. Indira Publishing House, Michigan.

Amrine, J.W.J., Stasny, T.A., Flechtmann, C.H.W., 2003. Revised keys to world genera of Eriophyoidea (Acari: Prostigmata). Indira Publishing House, Michigan.

Anonymous, 1928. Korean crop pest lists. Research report of agriculture encouraging experimental station. No. 15, 140 (In Japanese). Anonymous, 1973. Forest pest occurrence status in 1973. Korean J. 
Plant Protection 12(4), 169-170 (In Korean).

Anonymous, 1986. A list of plant diseases, insect pests, and weeds in Korea. $2^{\text {nd }}$ Edition. Korean Society of Plant Protection (In Korean)

Baker, E.W., Kono, T., O’Neill, N.R., 1986. Eriophyes zoysiae (Acari: Eriophyidae), a new species of eriophyid mite on Zoysia grass. International Journal of Acarology 12 (1), 3-6.

Channabasavanna, G.P., 1996. Sugarcane, Coffee and Tea, in: Lindquist E.E., Sabelis M.W., Bruin J. (Eds.), Eriophyoid Mites - Their Biology, Natural Enemies and Control. Elsevier Science Publ., Amsterdam, pp. 634-636.

Choi, K.M., Han, M.J., Ahn, S.B., Lee, S.H., Choi, D.R., 1992. Color atlas for ecology and control of insects pests of horticultural crops. Agricultural Sciences Institute, Rural Development Administration (In Korean).

Das, G.M., Sengupta, M., 1958. Observations on the pink mite Acaphylla theae (Watt) of tea in North-West India. J. Zool. Soc. India 10, 39-48.

De Lillo, E., Craemer, C., Amrine, J.W.J., Nuzzaci, G., 2010. Recommended procedures and techniques for morphological studies of Eriophyoidea (Acari: Prostigmata). Exp. Appl. Acarol. 51, 283-307.

Green, E.E., 1890. Insect pests of the tea plant. Colombo, Ceylion. Hong, X.Y., Zhang, Z.Q., 1996. The eriophyoid mites of China: An illustrated catalog and identification keys (Acari: Prostigmata: Eriophyoidea). Memoirs on Entomology, International 7.

Huang, T., 1972. Records of six eriophyid mites associated with plants in Korea. Journal of the Faculty of Science, Hokkaido University, Series VI, Zoology 18, 337-345.

Kadono, F., 1992. A new species of eriophyid mite injurious to tea plant in Japan (Acari: Eriophyidae). Acta Arachnologica 41, 149-152.

Kadono, F., 1995. Taxonomic studies on eriophyid mites on trees in Japan and ecological studies on the Japanese pear rust mite, Eriophyes chibaensis Kadono on pear trees (Acari: Eriophyoidea). Special Bulletin of the Chiba Prefectural Agricultural Experiment Station 30, 1-87.

Keifer, H.H., 1940a. Eriophyid Studies VIII. Bull. Cal. Dep. Agric. 29, 21-46.

Keifer, H.H., 1940b. Eriophyid Studies X. Bull. Cal. Dep. Agric. 29,
160-179.

Keifer, H.H., 1943. Eriophyid Studies XIII. Bull. Cal. Dep. Agric. $32,212-222$

Keifer, H.H., 1952. The eriophyid mites of California (Acarina: Eriophyidae). Bulletin of the California Insect Survey 2, 1-123pp.

Keifer, H.H., 1954. Eriophyid Studies XXII. Bull. Cal. Dep. Agric. 43, 121-131.

Keifer, H.H., 1955. Eriophyid mites, notes and new species (Acarina). The PAN-Pacific Entomologist 31 (3), 109-116.

Kim, C.H., 1965. The injured conditions of Erioophyes kuko Kishida. Korea Journal of Plant Protection 4, 65-66.

Kim, C.M., 1990. A new species of eriophyid mite Aceria zelkoviana sp. nov. (Acari, Eriophyidae) associated with Zelkova serratra Makino- (Ulmaceae) from Korea. International Journal of Acarology 16, 85-87.

Lee, H.S., Kadono, F., Kang, S.W., Park, C.G., Kim, K.J., 1999. New records of pear rust mite, Phyllocoptes pyrivagrans Kadono, from Korea (Acari: Eriophyidae). Korean J. Appl. Entomol. 38, $19-21$.

Manson, D.C.M., 1984. Eriophyoidea except Eriophyinae (Arachnida: Acari). Fauna of New Zealand, No. 4, 1-142.

Na, S.Y., Cho, M.R., Jeon, H.Y., Yiem, M.S., Oh, D.G., Park, K.W., 1998. Damage of garlic gall mite, Aceria tulipae (Kiefer) on stored garlic and its chemical control. Korean J. Appl. Entomol. 37, 81-89 (In Korean)

Nalepa, A., 1923. Index nominum quae ab a. 1886 eriophyidarum generibus, speciebus et subspecibus imposita sunt. Marcellia 29, 25-66.

Park, D.K., In, M.S., Park, I.H., 1996. Biology and control of newly found eriophyid mite on tomato I. Res. Rept. of Chungnam Agr. Tech. Admin. 463-468.

Watt, G., 1898. The pests and blights of the tea plant. Report of investigations conducted an Assam and to some extent also in Kangra, Office, Supt. Govt. Printing, Calcutta, India 1898, 400-408.

Westphal, E., Manson, D.C.M., 1996. Feeding effects on host plants, Gall formation and other distortions, in: Lindquist E.E., Sabelis M.W., Bruin J. (Eds.), Eriophyoid mites - Their biology, natural enemies and control. Elsevier Science Publ., Amsterdam, pp. 231-241 